\title{
MODELLING CONDENSATION AND THE INITIATION OF CHONDROGENESIS IN CHICK WING BUD MESENCHYMAL CELLS LEVITATED IN AN ULTRASOUND TRAP
}

\author{
Gareth Owain Edwards, W. Terence Coakley§, James R. Ralphs, and Charles W. Archer* \\ Connective Tissue Biology Laboratories, Cardiff School of Biosciences, Park Place, Cardiff, Wales, CF10 3AT \\ $\S$ Deceased
}

\begin{abstract}
Chick wing bud mesenchymal cell micromass culture allows the study of a variety of developmental mechanisms, ranging from cell adhesion to pattern formation. However, many cells remain in contact with an artificial substratum, which can influence cytoskeletal organisation and differentiation. An ultrasound standing wave trap facilitates the rapid formation of 2-D monolayer cell aggregates with a defined zero time-point, independent from contact with a surface. Aggregates formed rapidly (within $2 \mathrm{~min}$ ) and intercellular membrane spreading occurred at points of contact. This was associated with an increase in peripheral F-actin within 10 min of cell-cell contact and aggregates had obtained physical integrity by $30 \mathrm{~min}$. The chondrogenic transcription factor Sox 9 could be detected in cells in the ultrasound trap within $3 \mathrm{~h}$ (ultrasound exposure alone was not responsible for this effect). This approach facilitates the study of the initial cell-cell interactions that occur during condensation formation and demonstrates that a combination of cell shape and cytoskeletal organisation is required for the initiation and maintenance of a differentiated phenotype, which is lost when these phenomena are influenced by contact with an artificial substrate.
\end{abstract}

Keywords: Actin, chondrogenesis, mesenchyme, Sox9, ultrasound.

*Address for correspondence:

Charles W. Archer

Connective Tissue Biology Laboratories,

Cardiff School of Biosciences, Park Place,

Cardiff, Wales, CF10 3AT

E-mail: Archer@cf.ac.uk

\section{Introduction}

Chondrogenesis is a multi-step developmental process leading to the formation of skeletal tissues such as cartilage (reviewed in Delise et al., 2000 and Shimizu et al., 2007). Mesenchymal cells in the developing limb bud deposit extracellular matrix, form tightly-packed condensations, then differentiate into chondrocytes, proliferate and mature. Each step of chondrogenesis can be classified by the expression of a different set of transcription factors, cell adhesion molecules and extracellular matrix components. An expanded knowledge of the signalling pathways and mechanisms that lead to chondrogenic differentiation is of interest as it would aid technological progression in being able to repair damaged cartilage (Woods et al., 2007).

Chick wing bud mesenchymal cells (herein referred to as wing bud cells) provide a model system for studying chondrogenic differentiation in vitro following precartilaginous condensation (aggregation) and adhesion (Ahrens et al., 1977; Delise and Tuan, 2002a,b; Tuan, 2003; Yoon et al., 2000). Cell condensation occurs in vivo at stage 23 (Hamburger and Hamilton, 1951; Szebenyi et al., 1995) and is a prerequisite for chondrogenesis (Oberlender and Tuan, 1994). Chondrogenesis occurs in vitro when wing bud cells are cultured at a high density under anchorage-independent conditions, i.e. on agarose (Tavella et al., 1994) or as a micromass culture (Ahrens et al., 1977; Yoon et al., 2000). Cell aggregates form within 12-24 h of plating out (Ahrens et al., 1977).

The cell adhesion molecules NCAM (neural cell adhesion molecule) and $\mathrm{N}$-cadherin (neural cadherin) confer specific intercellular adhesion during condensation and are required for primary chondrogenesis (Delise et al., 2000; Delise and Tuan, 2002a; Stott et al., 1999; Tavella et al., 1994; Tuan, 2003). Functional inhibition of the latter factors with antibodies inhibits condensation, thus preventing chondrogenesis (Oberlender and Tuan, 1994; Widelitz et al., 1993). However, their continued expression following condensation also inhibits chondrogenesis (Fang and Hall, 1999; Tuan, 2003). Furthermore, inhibition of the expression of cadherin-7 through RNA interference in stage 22/23 chick wing bud mesenchymal cells prevented precartilaginous condensation and chondrogenic differentiation, as assessed through PNA and Alcian blue labelling (Kim et al., 2009). Gap junctions assembled from connexins form between cells and are required for chondrogenesis (Zhang et al., 2002). Coelho and Kosher (1991) demonstrated a high degree of gap junctional intercellular communication (GJIC) between cells in high density micromass cultures 
formed from stage 25 chick wing bud cells. Furthermore, they demonstrated that in mixed cultures of cells from stage 23/24 wing buds, GJIC occurs only in regions of cartilaginous differentiation, implying that GJIC may play a major role in this process (Coelho and Kosher, 1991). In addition to intercellular junctions, signalling via cyclic AMP has been shown to upregulate expression of type II collagen and the core protein of aggrecan in high-density cultures of limb mesenchymal cells, which does not occur when cells are subconfluent (Rodgers et al., 1989).

Expression of the transcription factor Sox9 is required for the initiation of chondrogenesis (Akiyama et al., 2002, 2004; Bi et al., 1999; Hardingham et al., 2006; Healy et al., 1999; Kulyk et al., 2000), resulting in the expression of Sox5, Sox6 (Akiyama et al., 2007), and type II collagen (Kulyk et al., 2000). Sox9 is first detected in stage 22 embryos at sites of mesenchymal condensation (Healy et al., 1999). Stage 24/25 chick wing bud cell micromass cultures showed increased Sox 9 mRNA expression from $2 \mathrm{~h}$ which peaked at between 20 and $65 \mathrm{~h}$ (Kulyk et al., 2000). Sox 9 expression is reduced in chondrocytes plated out at a low density, but is restored when cells treated with cytochalasin D (CytD) adopt a rounded morphology (Tew and Hardingham, 2006).

It would be desirable to form wing bud cell aggregates free from contact with an artificial substrate, allowing the role that initial cell-cell adhesion plays in orchestrating development to be studied in a manner more comparable to events in vivo although in the absence of extracellular matrix. Little is known about the initial spatio-temporal development of adhesion following cell-cell contact, which is central to cytoskeletal organisation, polarisation and development (Carthew, 2005; Grunwald, 1991). Two inherent problems exist with current methods of study, in that (a) adhesion to a substrate, e.g. a plastic culture dish coated with a natural or mimetic extracellular matrix, can orchestrate cytoskeletal remodelling via integrins (Cavalcanti-Adam et al., 2006; Chen et al., 2006; Feng et al., 2005; Galler et al., 2006; Yap and Kovacs, 2003), and (b) it is technically challenging to bring together populations of cells in a controlled and coordinated manner to study the progression of cell-cell adhesion with a defined zero time-point. Paired micropipettes (Chu et al., 2004) and optical trapping (Andersson et al., 2007; Hormeno and Arias-Gonzalez, 2006) are limited by the number of cells that can be manipulated. To address these difficulties, an ultrasound standing wave trap (USWT) has been developed. This levitates particles en masse, bringing them together to form a 2-D monolayer aggregate under continuous microscopic observation (Bazou et al., 2005a, b, 2006; Coakley et al., 2004; Hertz, 1995). Suspended particles are drawn into a pressure node (induced by the standing wave) in the surrounding aqueous medium, where inter-particle attractive forces (e.g. hydrophobicity or van der Waals) result in close molecular interactions between adjacent cells (Bazou et al., 2005b). Stable 2-D aggregates of interacting mammalian cells in physiological media can be rapidly assembled that form adhesive complexes and show cytoskeletal remodelling (Bazou et al., 2005a, 2006; Edwards et al., 2007). The current study was designed to determine how initial intercellular interactions could initiate chondrogenesis in limb buds in vitro, independent from contact with an artificial substratum, by levitation in an USWT.

\begin{tabular}{ll} 
& \multicolumn{1}{c}{ Abbreviations } \\
USWT & ultrasound standing wave trap \\
CytD & Cytochalasin D
\end{tabular}

\section{Materials and Methods}

\section{Chick wing bud cell preparation}

Fertilised White Leghorn chicken eggs (Henry Stewart \& Co., Ltd., Louth, Lincolnshire, UK) were incubated at $37^{\circ} \mathrm{C}$ and wing buds were dissected from stage 23 embryos (Ahrens et al., 1977; Cottrill et al., 1987; Hamburger \& Hamilton, 1951). Ectoderm was loosened with $2.5 \%$ trypsin·EDTA (Invitrogen, Paisley, U.K.) for $1 \mathrm{~min}$ at $4{ }^{\circ} \mathrm{C}$ and wing buds were pelleted by centrifugation for $3 \mathrm{~min}$ at $1500 \mathrm{~g}$. Ectoderm was removed under a stereomicroscope and wing bud cells separated by digestion in $0.05 \%$ trypsin. EDTA (Invitrogen) for $5 \mathrm{~min}$ at $37^{\circ} \mathrm{C}$. Cells were pelleted by centrifugation, washed in phosphatebuffered saline (PBS) (Sigma Aldrich, Poole, UK) and resuspended in supplemented growth medium [Dulbecco's Modified Eagle's Medium (Invitrogen); 1 \% v/v chick serum (Invitrogen); $10 \% \mathrm{v} / \mathrm{v}$ foetal bovine serum (Invitrogen); 2 mM L-glutamine (Invitrogen); $100 \mathrm{U} / \mathrm{ml}$ penicillin (Invitrogen); $100 \mu \mathrm{g} / \mathrm{ml}$ streptomycin (Invitrogen)]. Cells were filtered through $20 \mu \mathrm{m}$ Nitex (Sefar Ltd., Bury, UK) and viability was assessed on the basis of Trypan Blue dye exclusion (Sigma Aldrich). Concentration was adjusted to $1 \cdot 5 \times 10^{6}$ cells $\cdot \mathrm{ml}^{-1}$ and cells were incubated at $37^{\circ} \mathrm{C}$ in $5 \% \mathrm{CO}_{2} / 95 \%$ air.

Plated-out cells were cultured for $18 \mathrm{~h}$ to allow recovery of cell surface molecule expression following preparation (Oberlender and Tuan, 1994), then washed in PBS and incubated for $3 \mathrm{~min}$ at $37^{\circ} \mathrm{C}$ in Accutase (Sigma Aldrich). Cells were recovered by centrifugation and resuspended in serum-free medium [Dulbecco's Modified Eagle's Medium (Invitrogen); 2 mM L-glutamine (Invitrogen); 100 $\mathrm{U} / \mathrm{ml}$ penicillin (Invitrogen); $100 \mu \mathrm{g} / \mathrm{ml}$ streptomycin (Invitrogen)]. Cell suspensions were filtered through 20 $\mu \mathrm{m}$ Nitex, viability was assessed, and concentration adjusted as required. Where required, cells were treated with $1 \mu \mathrm{M}$ CytD in dimethylsulphoxide (DMSO) (Sigma Aldrich).

\section{The ultrasound trap}

The development and use of a half-wavelength USWT has been described previously (Bazou et al., 2005a, 2006; Coakley et al., 2004). In summary, a steel chassis was fabricated and fitted with a transducer below a sample chamber (depth $=0.5 \mathrm{~mm}$; effectively the wavelength of ultrasound in water $\div 2$ ). This was sealed with a quartz reflector, allowing optical access. Ports allowed the introduction and removal of samples. The transducer was driven at a nominal frequency of $1.5 \mathrm{MHz}$ by a sine wave generated by a Hewlett Packard (Bracknell, Berkshire, UK) 33120A signal generator. The USWT was mounted on an Olympus BX-41 microscope fitted with an F-View II 
camera (Olympus UK Ltd., London, UK), and connected to a computer running the Cell-A image acquisition software package (Olympus UK Ltd.). Low intensity pulsed ultrasound can up-regulate Sox 9 expression and enhance chondrogenesis (Hsu et al., 2006; Ikeda et al., 2006; Lee et al., 2006). Although the USWT is non-pulsed, a quarter-wavelength USWT (Martin et al., 2005) was used to determine whether ultrasound exposure could directly influence cells cultured on microscope slides.

\section{Aggregate image analysis}

Analysis of the dynamics of aggregation (based on area) allows the point of completion to be determined, when all initial cell-cell interactions have occurred. Cells were introduced into the USWT and aggregation was monitored by capturing images through a $\times 5$ objective lens every 10 $\mathrm{s}$ over $5 \mathrm{~min}$. All subsequent image analysis was carried out using Image-J 1.39 (Rasband, 1997-2007). Micrographs were converted to binary images by applying a threshold and the brush tool was used to ensure that thresholded cells were not in contact with any background noise in the image (Coakley et al., 2004). A region of interest (ROI) was selected around the thresholded aggregate using the wand tool, and ROI area plotted against aggregate age.

The development and strength of aggregate physical integrity (through cell-cell adhesion) was determined by sedimentation analysis (Coakley et al., 2004; Edwards et al., 2007). Ultrasound was terminated following aggregate formation which led to sedimentation onto the USWT surface. Aggregate area was measured following sedimentation and after a further $3 \mathrm{~min}$. Physical integrity was expressed as the \% increase in area at 3 min following sedimentation. Cells that were not strongly adhered to one another detached and rolled away from the aggregate on sedimentation, leading to an increase in aggregate area.

\section{Assessment of cell death}

Ultrasound has previously been employed as a cell disruption tool, on account of its ability to permeabilise cell membranes (Borthwick et al., 2005). Cell death can also lead to reduced membrane integrity, allowing the membrane-impermeable fluorescent dye ethidium homodimer to enter cells (Decherchi et al., 1997). Cells $\left(3 \times 10^{5}\right.$ cells $\left.\cdot \mathrm{ml}^{-1}\right)$ suspended in serum-free medium containing $1 \mu \mathrm{M}$ ethidium homodimer (Invitrogen) were introduced into the USWT and aggregation was initiated. Total aggregate area and the area of fluorescing cells at 3 min and $30 \mathrm{~min}$ were determined and the ratio of the area of fluorescing cells to the aggregate area indicated the proportion of cells with compromised membrane integrity within the aggregate (Edwards et al., 2007). As a control, cells were incubated in $1 \% \mathrm{v} / \mathrm{v}$ Triton X-100 (Sigma Aldrich) for $30 \mathrm{~min}$ at $4{ }^{\circ} \mathrm{C}$ to artificially permeabilise membranes prior to aggregation.

\section{Visualisation of F-actin}

F-actin remodelling occurs following cell-cell contact. Aggregates $\left(3 \times 10^{6}\right.$ cells $\left.\cdot \mathrm{ml}^{-1}\right)$ were recovered from the USWT, placed on 'Histobond' microscope slides (R. A. Lamb Ltd., Eastbourne, UK), and fixed in $90 \%$ v/v ethanol for $5 \mathrm{~min}$. Fixed cells were permeabilised with $0 \cdot 1 \% \mathrm{v} / \mathrm{v}$ Triton X-100 (Sigma Aldrich) in PBS for $15 \mathrm{~min}$ then blocked in $1 \% \mathrm{v} / \mathrm{v}$ goat serum (Sigma Aldrich) in PBS for $30 \mathrm{~min}$. F-actin was labelled with $10 \mathrm{U} / \mathrm{ml}$ phalloidinAlexa488 conjugate (Invitrogen) for $20 \mathrm{~min}$. Slides were washed in PBS, rinsed in distilled water, mounted in VectaShield containing DAPI (Vector Laboratories Ltd., Peterborough, UK), and observed under UV excitation with the Olympus BX41 microscope. Linear ROIs tangential to the cell-cell interface that extended into both cells provided F-actin intensity plot profile data. Experiments were carried out in triplicate. Five sets of measurements were taken from each of five fields of view per replicate, a Gaussian distribution was confirmed in Prism, and data were pooled to give a single reading for each replicate. To correct for background, the mean actin intensity value from between 2 and $4 \mu \mathrm{m}$ either side of the cell-cell interface was taken as a 'baseline' value and subtracted from all mean intensity values; hence values presented here essentially describe increased actin at the cell-cell interface compared to the neighbouring cytoplasm (Edwards et al., 2007).

\section{Indirect immunofluorescence detection of Sox9}

The transcription factor Sox 9 was used as an early-stage biomarker for the initiation of chondrogenesis. Cells $\left(3 \times 10^{6}\right.$ cells $\cdot \mathrm{ml}^{-1}$ ) were introduced into the USWT, and aggregates were removed and placed on Histobond slides at predetermined time points. These were fixed in $4 \% \mathrm{w} / \mathrm{v}$ paraformaldehyde (Sigma Aldrich) for $15 \mathrm{~min}$ at $4{ }^{\circ} \mathrm{C}$, then permeabilised and blocked (for $1 \mathrm{~h}$ ) as described above. Slides were incubated in $2 \mu \mathrm{g} \cdot \mathrm{ml}^{-1}$ rabbit anti-Sox 9 primary antibody (AbCam, Cambridge, Cambridgeshire, UK) for $2 \mathrm{~h}$, washed three times in PBS, then incubated for $1 \mathrm{~h}$ with $40 \mu \mathrm{g} \cdot \mathrm{ml}^{-1}$ goat anti-rabbit-FITC conjugate (AbCam). Slides were washed in PBS then distilled water, before being mounted in VectaShield (Vector Labs, Burlingame, CA, USA) containing 4,6-diamidino-2-phenylindole dihydrochloride (DAPI) and examined microscopically. Stage 23 wing buds were washed in phosphate buffered saline (PBS), fixed in $4 \%$ paraformaldehyde, then washed in PBS containing $5 \% \mathrm{w} / \mathrm{v}$ sucrose. Wing buds were mounted in OCT embedding matrix (R.A. Lamb, Eastbourne, East Sussex, UK) on dry ice and placed on a chuck for use with a cryostat (Bright OTF 5000; Bright, Huntingdon, Cambridgeshire, UK). Sections $(10 \mu \mathrm{m})$ were placed on 'Histobond' slides (VWR, Lutterworth, Leistershire, UK). Embedding matrix was removed by washing in PBS for $10 \mathrm{~min}$ and Sox9 was labelled as described above.

\section{Results}

\section{Aggregation characteristics}

Aggregates formed within $30 \mathrm{~s}$ of levitation and were complete within $2 \mathrm{~min}$ (Fig. 1A,B), indicating that all initial cell-cell interactions occur within this time. Aggregates were initially 2-D in form, as has been reported previously (Bazou et al., 2005b). However, due to the high concentration of cells employed, 3-D layering occurred 
A
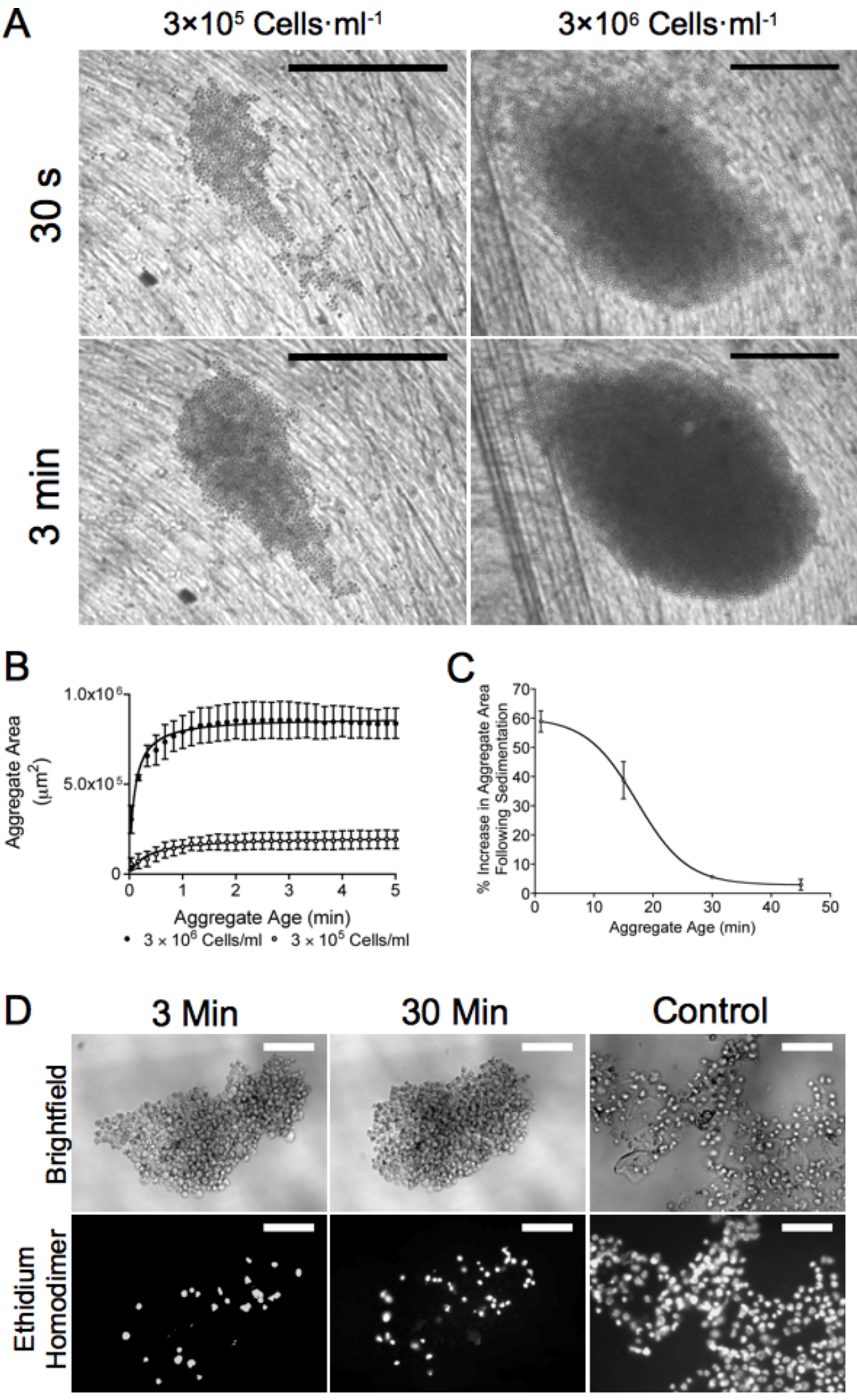

Figure 1. (A) Micrographs showing aggregate formation in the USWT between $30 \mathrm{~s}$ and $3 \mathrm{~min}$ at $3 \times 10^{5}$ cells $\cdot \mathrm{ml}^{-1}$ and $3 \times 10^{6}$ cells $\cdot \mathrm{ml}^{-1}$. Bar $=500 \mu \mathrm{m}$. (B) Aggregation was complete within $3 \mathrm{~min}$, and the rate-limiting factor was concentration. Maximum aggregate area was $2 \cdot 1 \times 10^{5} \pm 1 \cdot 5 \times 10^{4} \mu \mathrm{m}^{2}$ at $3 \times 10^{5}$ cells $\cdot \mathrm{ml}^{-1}$ and $8 \cdot 7 \times 10^{5} \pm 1 \cdot 9 \times 10^{4} \mu \mathrm{m}^{2}$ at $3 \times 10^{6}$ cells $\cdot \mathrm{ml}^{-1}$. (C) Aggregates developed physical integrity by $30 \mathrm{~min}$ ( $1 \mathrm{~min}: 58 \cdot 9 \pm 3 \cdot 6 \%$ increase; $15 \mathrm{~min}$ : $32 \cdot 6 \pm 2 \cdot 3 \%$ increase; $30 \mathrm{~min}: 5 \cdot 6 \pm 0 \cdot 2 \%$ increase; $45 \mathrm{~min}: 3 \cdot 0 \pm 1 \cdot 8 \%$ increase). There was no further increase in integrity beyond 30 min (one-tailed, unpaired $t$-test: $\mathrm{P}=0.076, \mathrm{DF}=3$ ). (D) Based on ethidium homodimer dye exclusion, ultrasound exposure in the USWT did not kill significant numbers of cells $(2 \cdot 98 \pm 0 \cdot 8 \%$ dye-loaded cells at $3 \mathrm{~min} ; 3 \cdot 89 \pm 0 \cdot 7 \%$ dye-loaded cells at $30 \mathrm{~min}$; one-tailed, unpaired $t$-test: $\mathrm{P}=0 \cdot 217, \mathrm{DF}=6$ ). Exposure to the detergent Triton X-100 resulted in dye entering cells, as a control demonstrating $100 \%$ compromised membrane integrity. $\mathrm{Bar}=50 \mu \mathrm{m}$. 

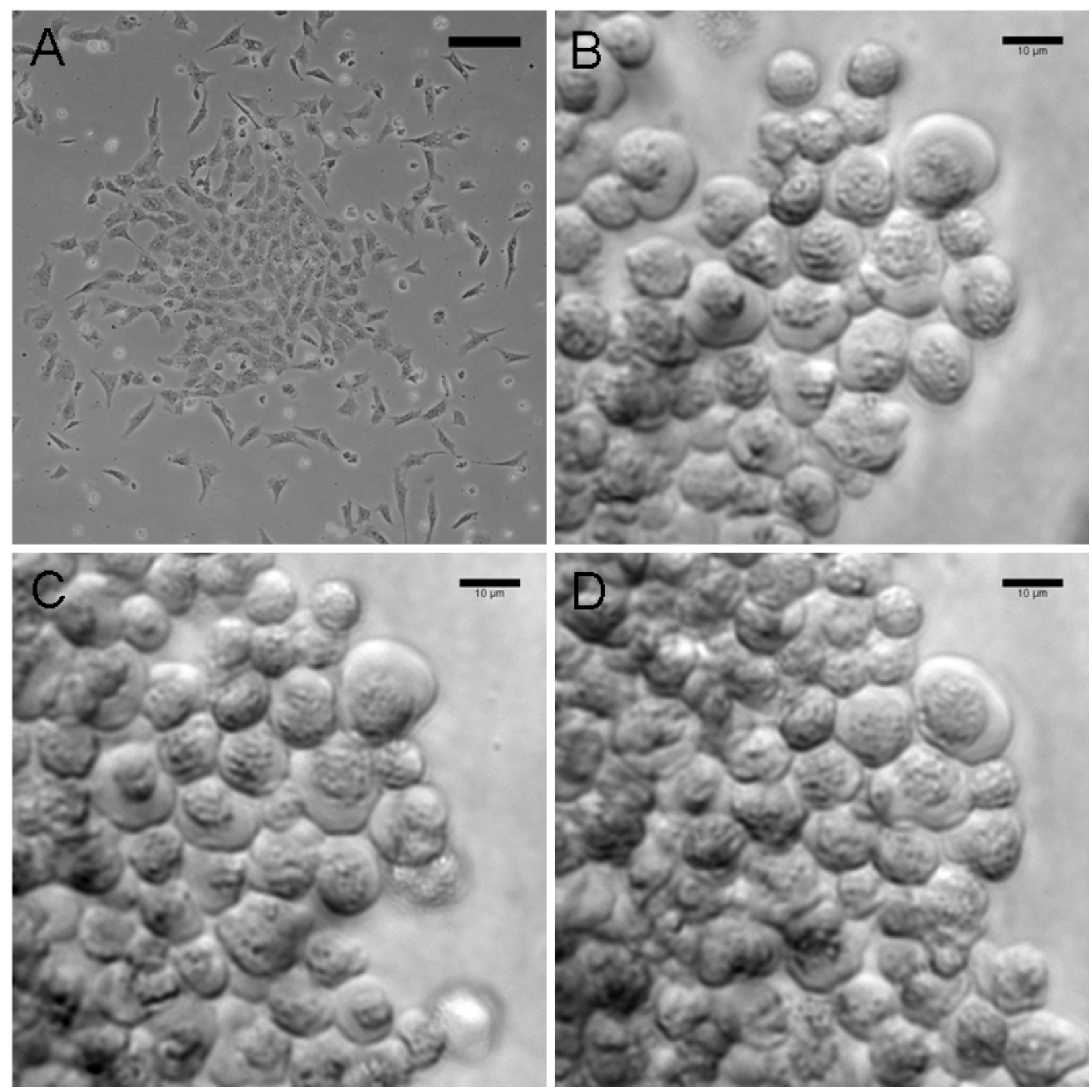

Figure 2. (A) Fibroblastic morphology of chick wing bud cells at $24 \mathrm{~h}$ following plating out. Bar=100 $\mu \mathrm{m}$. (B) Following $15 \mathrm{~s}$ in the USWT, voids were present between cells that retained a rounded morphology. Bar=10 $\mu \mathrm{m}$. (C) Following $25 \mathrm{~s}$ in the USWT, there was a marked reduction in intercellular voids and membrane spreading at points of cell-cell contact. Bar $=10 \mu \mathrm{m}$. (D) Following $55 \mathrm{~s}$, cells were tightly packed against one another. Bar=10 $\mu \mathrm{m}$.

in the centre of the aggregate. The lateral radiation force was approximately 100 times smaller than the axial radiation force (Woodside et al., 1997) and so at high cell concentrations, the lateral radiation force was not sufficient to maintain cells within a 2-D aggregate with a large diameter, and so cells are attracted by the axial radiation force and start piling up in the z-axis, thus giving rise to multiple layers within the middle of the aggregate. Physical integrity $\left(3 \times 10^{5}\right.$ cells $\left.\cdot \mathrm{ml}^{-1}\right)$ was assessed by retention of form following sedimentation and did not increase beyond 30 min (Figure 1C). Membrane integrity did not change significantly over $30 \mathrm{~min}$ (Fig. 1D). When membrane integrity was compromised with $1 \% \mathrm{v} / \mathrm{v}$ Triton X-100, all cells were labelled with ethidium homodimer (Fig. 1D).

At $24 \mathrm{~h}$, plated-out cells possessed a fibroblastic morphology (Fig. 2A). Cells in suspension initially possessed a rounded morphology, which was lost during aggregation as cells became more densely packed and flattened at points of contact (Fig. 2B-D, taken at $15 \mathrm{~s}, 25$ $\mathrm{S}$ and $55 \mathrm{~s}$ respectively). Aggregate formation was accompanied by a reduction in intercellular voids as cells became compacted together.

\section{Cytoskeletal reorganisation}

Cryosections were taken from stage 23 wing buds and labelled for F-actin, which was present around the cell periphery (Fig. 3A). In cells that were cultured on coverslips for $24 \mathrm{~h}, \mathrm{~F}$-actin was present in the form of stress fibres (Fig. 3B). Following incubation with $1 \mu \mathrm{M}$ CytD for $17.5 \mathrm{~h}$, the cells rounded up and depolymerised 

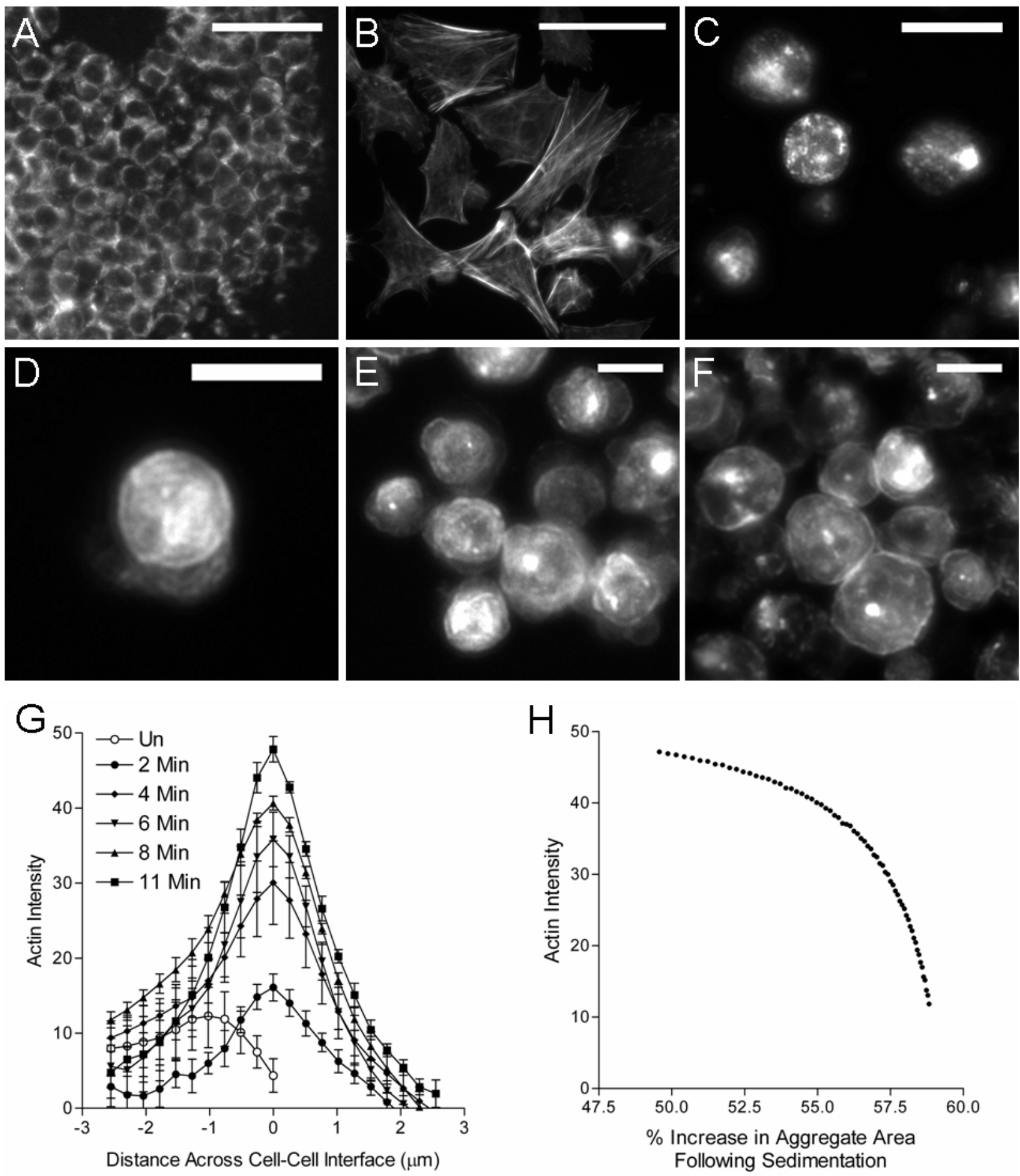

Figure 3. (A) Actin in chick wing bud cryosections labelled with Alexa488-conjugated Phalloidin was present at the cell periphery. Bar $=50 \mu \mathrm{m}$. (B) At $24 \mathrm{~h}$ there was an extensive network of stress fibres in plated out, fibroblastic wing bud cells. Bar $=20 \mu \mathrm{m}$. (C) Treatment of chick wing bud cells with $1 \mu \mathrm{M}$ Cytochalasin-D resulted in a loss of F-actin stress fibres and a more rounded morphology. Bar $=20 \mu \mathrm{m}$. (D) F-actin was cytoplasmic in unsonicated wing bud cells. Bar $=10 \mu \mathrm{m}$. (E) By 2 min in the USWT, some F-actin was located at the cell periphery. Bar=10 $\mu \mathrm{m}$. (F) F-actin was localized at the cell periphery following $11 \mathrm{~min}$. Bar=10 $\mu \mathrm{m}$. (G) Fluorescence intensity plot profiles demonstrated that junctional F-actin at the cell-cell interface increased with increasing aggregate age. (H) Aggregate physical integrity (expressed as the $\%$ increase in aggregate area following sedimentation) correlated with junctional F-actin intensity. 

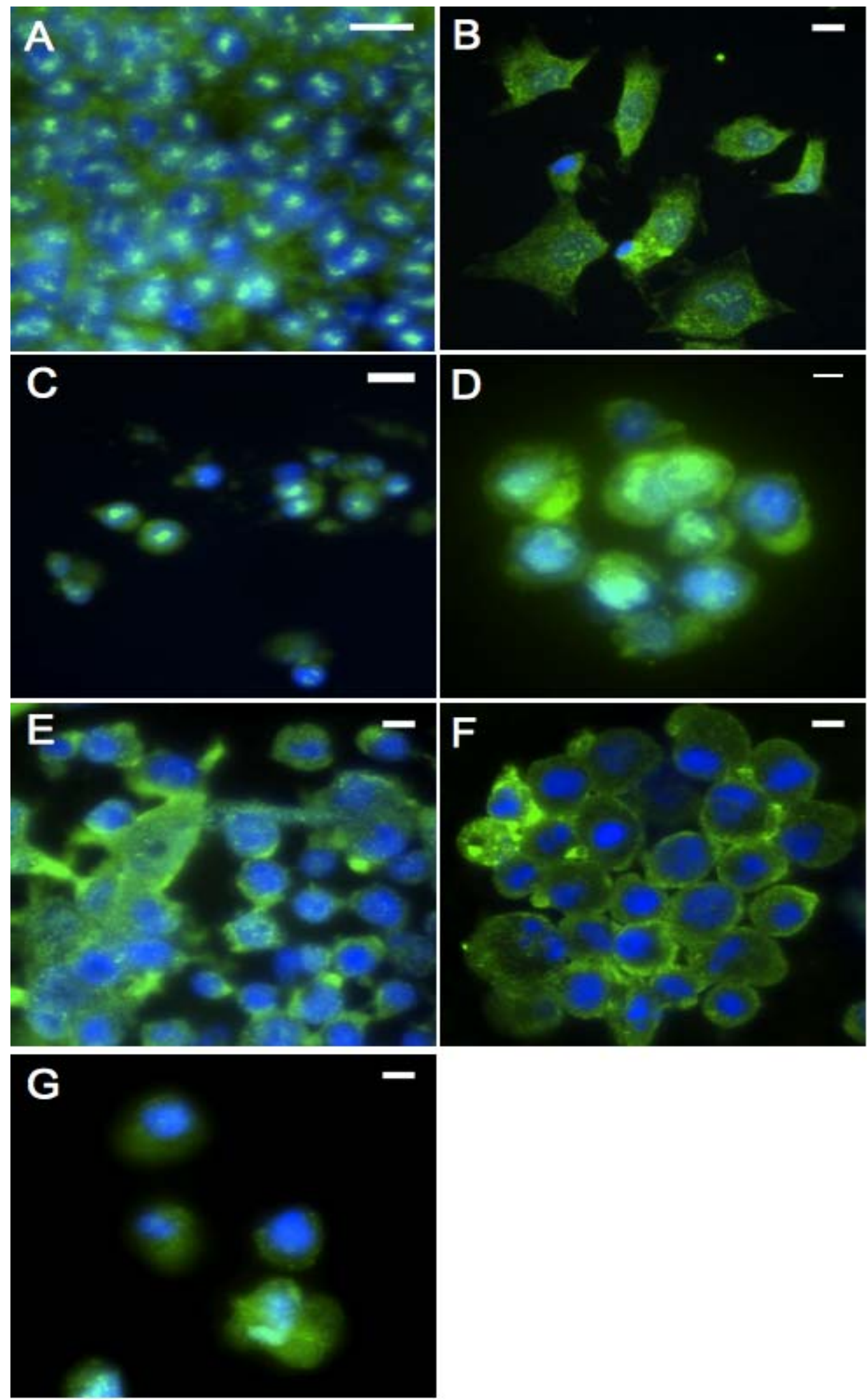

Figure 4. (A) Nuclear localization of Sox 9 in cryosectioned stage 23 chick wing bud condensations. Nuclei were labelled with DAPI. Bar $=10 \mu \mathrm{m}$. (B) There was no nuclear localisation of Sox 9 in isolated cells at $24 \mathrm{~h}$ post-plating out. Bar $=10 \mu \mathrm{m}$. (C) Treatment of cells with $1 \mu \mathrm{M}$ Cytochalasin-D for $17 \cdot 5 \mathrm{~h}$ lead to a rounded-up morphology and nuclear localisation of Sox9. Bar=10 $\mu \mathrm{m}$. (D) Nuclear localisation of Sox9 in cells taken from $3 \mathrm{~h}$ USWT aggregates. Bar $=10 \mu \mathrm{m}$. (E) There was no nuclear localisation of Sox 9 in isolated cells plated out for $3 \mathrm{~h}$. Bar=10 $\mu \mathrm{m}$. (F) Nuclear localisation of Sox 9 was reduced in cells from $3 \mathrm{~h}$ aggregates removed from the USWT and plated out for a further $3 \mathrm{~h}$. Bar $=10 \mu \mathrm{m}$. (G) When plated out cells were exposed to the same regime of ultrasound as $3 \mathrm{~h}$ USWT aggregates, there was no nuclear localisation of Sox9. Bar $=10 \mu \mathrm{m}$. 
their actin stress fibres (Fig. 3C). F-actin was located in the cytoplasm of unsonicated cells that were fixed immediately following plating out onto 'Histobond' slides (Fig. 3D). Removal from the trap to fixation took $1 \mathrm{~min}$, and this time is included in the following analysis (the same is true for the immunofluorescence results). By 2 min incubation in the USWT, F-actin was mainly cytoplasmic, but had begun to localise to the cell periphery at points of cell-cell contact (Fig. 3E). Strong labelling of junctional F-actin was evident within 11 min (Fig. 3F) of cell-cell contact. The fluorescence intensity of labelled Factin at the cell-cell interface was quantified and increased with time post-contact (Fig. 3G). Peak actin fluorescence intensity was plotted against the percentage increase in aggregate area following sedimentation (from Fig. 1C) at comparable time-points (Fig. $3 \mathrm{H}$ ). This plot indicated that increased junctional F-actin and the development of aggregate physical strength occurred along the same timescale.

\section{Sox9 Expression}

Nuclear localisation of Sox 9 was evident in cryosections of stage 23 wing buds (Fig. 4A; $n=6$ ); however, this was lost when isolated cells were plated out for $24 \mathrm{~h}$ (Fig. 4B; $\mathrm{n}=6$ ). When cells were treated with $1 \mu \mathrm{M} \mathrm{CytD}$ for $17 \cdot 5 \mathrm{~h}$, they rounded up and nuclear localisation of Sox 9 was again apparent (Fig. 4C; $n=6$ ). Nuclear localisation of Sox9 was also evident in USWT aggregates of cells following $3 \mathrm{~h}$ levitation (Figure 4D; $n=10$ ); however, there was no nuclear localisation of Sox 9 in cells that had been plated out for $3 \mathrm{~h}$ (Fig. 4E; n=8). When $3 \mathrm{~h}$ USWT aggregates were removed from the USWT and plated out in monolayer for a further $3 \mathrm{~h}$, there was a subsequent reduction in the nuclear localisation of Sox9 (Fig. 4F; $\mathrm{n}=8$ ). There was no nuclear localisation of Sox 9 in cells that had been plated out as a monolayer and subsequently exposed to the same regime of ultrasound (Fig. $4 \mathrm{G} ; \mathrm{n}=2$ ).

\section{Discussion}

The current study was designed to determine how initial intercellular interactions could initiate chondrogenesis in limb buds in vitro, independent from contact with an artificial substratum. Cells in the USWT began to form 2D monolayer aggregates within $30 \mathrm{~s}$ of commencing ultrasound exposure. This process was essentially complete within $2 \mathrm{~min}$. The majority of initial cell-cell contact events occur within this time, giving a synchronised zero timepoint for studying cytoskeletal remodelling and the initiation of chondrogenesis en masse. In contrast, methods such as micromass culture that retain some contact with an artificial substrate have no defined zero time-point from which to study cell-cell interactions in real time en masse. Aggregation occurred more rapidly at a higher cell concentration and the time required for aggregation was comparable with previous studies employing the USWT. Neural cell (C6), chondrocyte and HepG2 cell aggregates all began to form within $30 \mathrm{~s}$ of commencing sonication and were complete within 5 min (Bazou et al., 2005a; Bazou et al., 2006; Edwards et al., 2007). Aggregates of chick wing bud cells had begun to develop physical integrity by $30 \mathrm{~min}$, twice as long as for HepG2 cells (Edwards et al., 2007). Mature chondrocyte aggregates obtain physical integrity within $1 \mathrm{~h}$ (Bazou et al., 2006).

Ultrasound exposure did not compromise membrane integrity; hence cells remain viable following aggregation in the USWT. The USWT did not affect the viability of chick cells, C6 neural cells (Bazou et al., 2005a) or HepG2 liver cells (Edwards et al., 2007). The influence of ultrasound may extend beyond inducing aggregation by directly affecting cells. However, this notion seems unlikely, since the aggregate forms at a pressure node where both pressure and the axial direct radiation force that bring the cells into close proximity are zero (Kuznetsova and Coakley, 2004). At this scale, hydrophobic interactions and van der Waals forces influence intercellular attraction (Coakley et al., 2004), and when two spherical particles of a diameter of $15 \mu \mathrm{m}$ are brought closer than $50 \mathrm{~nm}$ together (at an acoustic pressure of $0.27 \mathrm{MPa}$ ), these outweigh any attractive acoustic forces between particles (Bazou et al., 2005b). Membrane spreading and morphological changes following cell-cell contact are a biological phenomena and are not influenced by ultrasound, as they were inhibited when HepG2 cells incubated with CytD were brought together in the USWT (unpublished data).

Plated out wing bud cells initially adopted a fibroblastic morphology, whereas cells in the USWT followed a distinct pattern of morphological changes during aggregation. Cell packing and membrane spreading between cells led to flattened edges at points of contact. Cell compaction and membrane spreading at the contact zone between cells brought together in the USWT (Bazou et al., 2005a; Coakley et al., 2004; Coakley and Bazou, 2005; Edwards et al., 2007) leads to reduced intercellular space (Coakley et al., 2004). These changes are comparable to compaction during prechondrogenic condensation in the developing limb, where cell density is increased without proliferation (Delise et al., 2000), leading to increased cell packing and a loss of intercellular spaces (Thorogood and Hinchliffe, 1975).

Reorganisation of F-actin following cell-cell contact occured rapidly, and within 11 min resembled F-actin in stage 23 chick wing bud cryosections, e.g. a peripheral or cortical distribution. Unlike plated out cells, there were no stress fibres. This has also been observed in USWT aggregates of C6 neural cells (Bazou et al., 2005a), chondrocytes (Bazou et al., 2006) or HepG2 cells (Edwards et al., 2007). Stabilisation of junctional F-actin and the development of physical integrity occurred on the same timescale. Previous studies of actin reorganisation following cell-cell contact have employed cells grown on an artificial substrate, often using a 'calcium switch' to induce cadherin-mediated cell-cell contact (Ivanov et al., 2004; Zhang et al., 2005). Adhesion molecules such as cadherins (Goodwin and Yap, 2004; Leckband and Prakasam, 2006; Prakasam et al., 2006) and cell adhesion molecules (CAMs) (Crossin and Krushel, 2000; Walmod et al., 2004) facilitate specific interactions and cellular responses. Specific cell adhesion is vital in maintaining tissue segregation (Pokutta and Weis, 2007; Prakasam et 
al., 2006). Adhesive molecules transmit signals or developmental cues into the cell (Gao et al., 2006; Modarresi et al., 2005) and coordinate cytoskeletal remodelling (Bamji, 2005; Goodwin and Yap, 2004; Yap and Kovacs, 2003). Both F-actin and E-cadherin are required for strong intercellular adhesion between mouse sarcoma cells brought together using a pair of micropipettes (Chu et al., 2004).

By rapidly generating 2-D aggregates of chick limb bud cells in the USWT, their behaviour following cell contact can be used to model the early stages of prechondrogenic condensation in vitro, away from contact with an artificial substrate. Contact with an artificial substrate can inhibit the expression of a chondrogenic phenotype (Zanetti and Solursh, 1984). To determine how cell shape, cytoskeletal architecture, cell-cell contact and cell-substrate contact can influence chondrogenesis, expression of the chondrogenic transcription factor Sox 9 was employed as a biomarker. In stage 23 chick wing buds, Sox 9 demonstrated strong nuclear localisation, which was lost when cells were isolated and plated out for $24 \mathrm{~h}$. Nuclear localisation of Sox9 was recovered when cells were treated with CytD, along with the adoption of a rounded morphology and a loss of F-actin stress fibres; as seen in plated-out mature human chondrocytes (Tew and Hardingham, 2006). When plated out cells were levitated as an aggregate for $3 \mathrm{~h}$ in the USWT, Sox 9 again became localised to the nucleus. Moreover, when these cells were plated out for a further $3 \mathrm{~h}$, there was a reduction in nuclear Sox9, suggesting that contact with an artificial substrate directly influences the expression of a chondrogenic phenotype. These cells remained in contact with one another (comparable to cells in a high-density micromass culture), and so it is suggested that this loss of Sox 9 occurs due to reorganisation of the F-actin cytoskeleton, rather than a loss of cell-cell contact. Sox 9 expression can be increased in murine embryonic stem cells within $4 \mathrm{~h}$ by disrupting cytoskeletal organisation with CytD (Zhang et al., 2006). Cell shape, actin distribution and Sox 9 expression were comparable in cryosections and USWT aggregates (e.g. a rounded morphology in tightly packed cells, showing peripheral F-actin organisation and nuclear localisation of Sox9). These differed from cells that were plated out on an artificial substrate, which had a flattened morphology, F-actin stress fibres and did not express Sox9, demonstrating that cell morphology and cytoskeletal architecture seen in plated out cells directly contributes to a dedifferentiated phenotype.

Previous reports have suggested that pulsed ultrasound exposure can enhance Sox9 expression (Hsu et al., 2006; Ikeda et al., 2006; Lee et al., 2006), which may explain the expression of Sox 9 in cells levitated in the USWT. A constant pressure of $4 \cdot 5 \mathrm{kPa}$ applied to stage 23 chick wing bud cells embedded in agarose had no effect on chondrogenesis by day 8 , but a cyclic pressure of $9 \cdot 0 \mathrm{kPa}$ doubled the number of cartilaginous nodules by day 8 (Elder et al., 2000). However, the USWT is not a pulsed source, and so this possibility may be discounted. The acoustic pressure in the half-wavelength USWT has previously been determined to be $110 \mathrm{kPa}$ (Edwards et al., 2007), and the acoustic pressure experienced at the pressure node where the aggregate forms is zero (Kuznetsova and Coakley, 2004). The important parameter in ultrasound systems is the pressure, as it is a physical parameter transferable to other systems for comparison. The pressure in both systems was calculated and shown to be of the same order of magnitude $(110 \mathrm{kPa})$. Furthermore, the position of the cells relative to the transducer and reflector was identical in both systems (for a schematic representation, refer to Kuznetsova and Coakley, 2007). Cells plated out on slides and exposed to the same regime of ultrasound in the quarter-wavelength USWT showed no increase in the nuclear localisation of Sox 9, confirming that ultrasound exposure in the USWT could not directly influence chondrogenesis.

Through the employment of the USWT, we have been able to study the initial cell-cell interactions that initiate chondrogenesis during limb development independent from cell-substrate interactions. During condensation, cells come together and are compacted and take on a rounded morphology, show peripheral actin organisation, form adhesive complexes and gap junctions, then begin to express Sox9 (Coelho and Kosher, 1991; Kulyk et al., 2000; Oberlender and Tuan, 1994; Tuan, 2003). These processes may initiate chondrogenesis in the developing embryo. Previously, it has not been possible to study these initial interactions en masse. The USWT allows these phenomena to be studied with a defined zero time-point and free from contact with an artificial substrate.

\section{Acknowledgements}

This work was supported by the Biotechnology and Biological Sciences Research Council, Grant No. BB/ C515220/1. We would like to acknowledge Dr. Rebecca Williams for help with the chick wing bud mesenchymal cell preparation and Mr. Keith Oliver for constructing the chambers used during the study.

\section{References}

Ahrens PB, Solursh M, Reiter RS (1977) Stage related capacity for limb chondrogenesis in culture. Dev Biol 60: 69-82.

Akiyama H, Chaboissier MC, Martin JF, Schedl A, de Crombrugghe B (2002) The transcription factor Sox 9 has essential roles in successive steps of the chondrocyte differentiation pathway and is required for expression of Sox5 and Sox6. Genes Dev 16: 2813-2828.

Akiyama H, Lyons JP, Mori-Akiyama Y, Yang X, Zhang R, Zhang Z, Deng JM, Taketo MM, Nakamura T, Behringer RR, McCrea PD, de Crombrugghe B (2004) Interactions between Sox 9 and $\beta$-catenin control chondrocyte differentiation. Genes Dev 18: 1072-1087.

Akiyama H, Stadler HS, Martin JF, Ishii TM, Beachy PA, Nakamura T, de Crombrugghe B (2007) Misexpression of Sox 9 in mouse limb bud mesenchyme induces polydactyly and rescues hypodactyly mice. Matrix Biol 26: 224-233. 
Andersson M, Madgavkar A, Stjerndahl M, Wu Y, Niehren S, Mustafa K, Arvidson K and Wennerberg A (2007) Using optical tweezers for measuring the interaction forces between human bone cells and implant surfaces: system design and force calibration. Rev Sci Instrum 78: 074302-1-074302-8.

Bamji SX (2005) Cadherins: actin with the cytoskeleton to form synapses. Neuron 47: 175-178.

Bazou D, Dowthwaite GP, Khan IM, Archer CW, Ralphs JR, Coakley WT (2006) Gap junctional intercellular communication and cytoskeletal organisation in chondrocytes in suspension in an ultrasound trap. Mol Membrane Biol 23: 195-205.

Bazou D, Foster GA, Ralphs JR, Coakley WT (2005a) Molecular adhesion development in a neural cell monolayer forming in an ultrasound trap. Mol Membr Biol 22: 229-240.

Bazou D, Kuznetsova L, Coakley WT (2005b) Physical environment of 2-D animal cell aggregates formed in a short pathlength ultrasound standing wave trap. Ultrasound Med Biol 31: 423-430.

Bi W, Deng JM, Zhang Z, Behringer RR, de Crombrugghe B (1999) Sox9 is required for cartilage formation. Nat Genet 22: 85-89.

Borthwick KA, Coakley WT, McDonnell MB, Nowotny H, Benes E, Groschl M (2005) Development of a novel compact sonicator for cell disruption. J Microbiol Meth 60: 207-216.

Carthew RW (2005) Adhesion proteins and the control of cell shape. Curr Opin Genet Dev 15: 358-363.

Cavalcanti-Adam EA, Micoulet A, Blümmel J, Auernheimer J, Kessler H, Spatz JP (2006) Lateral spacing of integrin ligands influences cell spreading and focal adhesion assembly. Eur J Cell Biol 85: 219-224.

Chen M, Chen SC, Pallen CJ (2006) Integrin-induced tyrosine phosphorylation of protein-tyrosine phosphatase$\mathrm{a}$ is required for cytoskeletal reorganization and cell migration. J Biol Chem 281: 11972-11980.

Chu YS, Thomas WA, Eder O, Pincet F, Perez E, Thiery JP, Dufour S (2004) Force measurements in E-cadherinmediated cell doublets reveal rapid adhesion strengthened by actin cytoskeleton remodelling through Rac and Cdc42. J Cell Biol 167: 1183-1194.

Coakley WT, Bazou D (2005) Particle and cell manipulation by radiation force in ultrasound standing waves. In: Bubble and Particle Dynamics in Acoustic Fields: Modern Trends and Applications. (Doinikov AA, ed) Research Signpost Transworld Research Network pp 313-338.

Coakley WT, Bazou D, Morgan J, Foster GA, Archer CW, Powell K, Borthwick KAJ, Twomey C, Bishop J (2004) Cell-cell contact and membrane spreading in an ultrasound trap. Colloids Surf B: Biointerfaces 34: 221230.

Coelho CN, Kosher RA (1991) Gap junctional communication during limb cartilage differentiation. Dev Biol 144: 47-53.

Cottrill CP, Archer CW, Wolpert L (1987) Cell sorting and chondrogenic aggregate formation in micromass culture. Dev Biol 122: 503-515.
Crossin KL, Krushel LA (2000) Cellular signalling by neural cell adhesion molecules of the immunoglobulin superfamily. Dev Dyn 218: 260-279.

Decherchi P, Cochard P, Gauthier P (1997) Dual staining assessment of Schwann cell viability within whole peripheral nerves using calcein-AM and ethidium homodimer. J Neurosci Methods 71: 205-213.

Delise AM, Fischer L, Tuan RS (2000) Cellular interactions and signalling in cartilage development. Osteoarthritis Cartilage 8: 309-334.

Delise AM, Tuan RS (2002a) Analysis of N-cadherin function in limb mesenchymal chondrogenesis in vitro. Dev Dyn 225: 195-204.

Delise AM, Tuan RS (2002b) Alterations in the spatiotemporal expression pattern and function of N-cadherin inhibit cellular condensation and chondrogenesis of limb mesenchymal cells in vitro. J Cell Biochem 87: 342-359.

Edwards GO, Bazou D, Kuznetsova LA, Coakley WT (2007) Cell adhesion dynamics and actin cytoskeleton reorganisation in HepG2 cell gggregates. Cell Comm Adhes 14: 9-20.

Elder SH, Kimura JH, Soslowsky LJ, Lavagnino M, Goldstein SA (2000) Effect of compressive loading on chondrocyte differentiation in agarose cultures of chick limb-bud cells. J Orthop Res 18: 78-86.

Fang J, Hall BK (1999) NCAM is not required for initiation of secondary chondrogenesis: the role of NCAM in skeletal condensation and differentiation. Int J Dev Biol 43: 335-342.

Feng Z, Chen WN, Lee PVS, Liao K, Chan V (2005) The influence of GFP-actin expression on the adhesion dynamics of HepG2 cells on a model extracellular matrix Biomaterials 26: 5348-5358.

Galler AB, Arguinzonis MIG, Baumgartner W, Kuhn M, Smolenski A, Simm A, Reinhard M (2006) VASPdependent regulation of actin cytoskeleton rigidity, cell adhesion, and detachment. Histochem Cell Biol 125: 457 474.

Gao M, Sotomayor M, Villa E, Lee EH, Schulten K (2006) Molecular mechanisms of cellular mechanics. Phys Chem Chem Phys 8: 3692-3706.

Goodwin M, Yap AS (2004) Classical cadherin adhesion molecules: coordinating cell adhesion, signalling and the cytoskeleton. J Mol Hist 35: 839-844.

Grunwald GB (1991) Developmental Biology: A Comprehensive Synthesis. 7 (Gilbert SF, ed) Plenum Press, New York. pp 129-157.

Hamburger V and Hamilton HL (1951) A series of normal stages in the development of the chick embryo. $\mathrm{J}$ Morphol 88: 49-92.

Hardingham TE, Oldershaw RA, Tew SR (2006) Cartilage, Sox 9 and Notch signals in chondrogenesis. J Anat 209: 469-480.

Healy C, Uwanogho D, Sharpe PT (1999) Regulation and role of Sox9 in cartilage formation. Dev Dyn 215: 6978.

Hertz HM (1995) Standing-wave acoustic trap for nonintrusive positioning of microparticles. J Appl Phys 78: 4845-4849. 
Hormeno S, Arias-Gonzalez JR (2006) Exploring mechanochemical processes in the cell with optical tweezers. Biol Cell 98: 679-695.

Hsu S, Kuo C, Whu SW, Lin C, Tsai C (2006) The effect of ultrasound stimulation versus bioreactors on neocartilage formation in tissue engineering scaffolds seeded with human chondrocytes in vitro. Biomolecular Eng 23: 259-264.

Ikeda K, Takayama T, Suzuki N, Shimada K, Otsuka K, Ito K (2006) Effects of low-intensity pulsed ultrasound on the differentiation of C2C12 cells. Life Sci 79: 19361943.

Ivanov AI, McCall IC, Parkos CA, Nusrat A (2004) Role for actin filament turnover and a myosin II motor in cytoskeleton-driven disassembly of the epithelial apical junctional complex. Mol Biol Cell 15: 2639-2651.

Kim D, Kang SS, Jin EJ (2009) Alterations in the temporal expression and function of cadherin-7 inhibit cell migration and condensation during chondrogenesis of chick limb mesenchymal cells in vitro. J Cell Physiol 221: 161-170.

Kulyk WM, Rodgers BJ, Greer K, Kosher RA (1989) Promotion of embryonic chick limb cartilage differentiation by transforming growth factor beta. Dev Biol 135: 424-430.

Kulyk WM, Franklin JL, Hoffman LM (2000) Sox9 expression during chondrogenesis in micromass cultures of embryonic limb mesenchyme. Exp Cell Res 255: $327-$ 332 .

Kuznetsova LA, Coakley WT (2004) Microparticle concentration in short path length ultrasonic resonators: role of radiation pressure and acoustic streaming. J Acoust Soc Am 116: 1956-1965.

Kuznetsova LA, Coakley WT (2007) Applications of ultrasound streaming and radiation force in biosensors. Biosens Bioelectron 22: 1567-1577.

Leckband D, Prakasam A (2006) Mechanism and dynamics of cadherin adhesion. Ann Rev Biomed Eng 8: 259-287.

Lee HJ, Choi BH, Min B, Son YS, Park SR (2006) Low-intensity ultrasound stimulation enhances chondrogenic differentiation in alginate culture of mesenchymal stem cells. Artif Organs 30: 707-715.

Martin SP, Townsend RJ, Kuznetsova LA, Borthwick KAJ, Hill M, McDonnell MB, Coakley WT (2005) Spore and micro-particle capture on an immunosensor surface in an ultrasound standing wave system. Biosens Bioelectron 21: 758-767.

Modarresi R, Lafond T, Roman-Blas JA, Danielson KG, Tuan RS, Seghatoleslami MR (2005) N-cadherin mediated distribution of $\beta$-catenin alters MAP kinase and BMP-2 signalling on chondrogenesis-related gene expression. J Cell Biochem 95: 53-63.

Oberlender SA, Tuan RS (1994) Expression and functional involvement of N-cadherin in embryonic limb chondrogenesis. Development 120: 177-187.

Pokutta S, Weis WI (2007) Structure and mechanism of cadherins and catenins in cell-cell contacts. Ann Rev Cell Dev Biol 23: 237-261.
Prakasam AK, Maruthamuthu V, Leckband DE (2006) Similarities between heterophilic and homophilic cadherin adhesion. Proc Natl Acad Sci USA 103: 15434-15439.

Rasband WS (1997-2007) ImageJ. US National Institutes of Health Bethesda Maryland USA http:// rsb.info.nih.gov/ij/.

Rodgers BJ, Kulyk WM, Kosher RA (1989) Stimulation of limb cartilage differentiation by cyclic AMP is dependent on cell density. Cell Differ Dev 28: 179-187.

Shimizu H, Yokoyama S, Asahara H (2007) Growth and differentiation of the developing limb bud from the perspective of chondrogenesis. Develop Growth Differ 49: 449-454.

Stott NS, Jiang TX, Chuong CM (1999) Successive formative stages of precartilaginous mesenchymal condensations in vitro: Modulation of cell adhesion by Wnt-7A and BMP-2. J Cell Physiol 180: 314-324.

Szebenyi G, Savage MP, Olwin BB, Fallon JF (1995) Changes in the expression of fibroblast growth factor receptors mark distinct stages of chondrogenesis in vitro and during chick limb skeletal patterning. Dev Dyn 204: 446-456.

Tavella S, Raffo P, Tacchetti C, Cancedda R, Castagnola $\mathrm{P}$ (1994) NCAM and N-cadherin expression during in vitro chondrogenesis. Exp Cell Res 215: 354-362.

Tew SR, Hardingham TE (2006) Regulation of Sox 9 mRNA in human articular chondrocytes involving p38 MAPK activation and mRNA stabilization. J Biol Chem 281: 39471-39479.

Thorogood PV, Hinchliffe JR (1975) An analysis of the condensation process during chondrogenesis in the embryonic chick hind limb. J Embryol Exp Morphol 33: 581-606.

Tuan RS (2003) Cellular signalling in developmental chondrogenesis: N-cadherin, Wnts, and BMP-2. J Bone Joint Surg Am 85: 137-141.

Walmod PS, Kolkova K, Berezin V, Bock E (2004) Zippers make signals: NCAM-mediated molecular interactions and signal transduction. Neurochem Res 29: 2015-2035.

Widelitz RB, Jiang TX, Murray BJ, Chuong CM (1993) Adhesion molecules in skeletogenesis: II. Neural cell adhesion molecules mediate precartilaginous mesenchymal condensations and enhance chondrogenesis. J Cell Physiol 156: 399-411.

Woods A, Wang G, Dupuis H, Shao Z, Bier F (2007) Rac1 signalling stimulates $\mathrm{N}$-cadherin expression, mesenchymal condensation and chondrogenesis. J Biol Chem 282: 23500-23508.

Yap AS, Kovacs EM (2003) Direct cadherin-activated cell signalling: a view from the plasma membrane. J Cell Biol 160: 11-16.

Yoon YM, Oh CD, Kim DY, Lee YS, Park JW, Huh TL, Kang SS, Chun JS (2000) Epidermal growth factor negatively regulates chondrogenesis of mesenchymal cells by modulating the protein kinase $\mathrm{C}-\alpha$, Erk-1, and p38 MAPK signalling pathways. J Biol Chem 275: 1235312359.

Zanetti NC, Solursh M (1984) Induction of chondrogenesis in limb mesenchymal cultures by 
disruption of the actin cytoskeleton. J Cell Biol 99: 115123.

Zhang J, Betson M, Erasmus J, Zeikos K, Bailly M, Cremer LP, Braga VMM (2005) Actin at cell-cell junctions is composed of two dynamic and functional populations. J Cell Sci 118: 5549-5562.

Zhang W, Green C, Stott NS (2002) Bone morphogenetic protein-2 modulation of chondrogenic differentiation in vitro involves gap junction-mediated intercellular communication. J Cell Physiol 193: 233-243.

Zhang Z, Messana J, Hwang NSH, Elisseeff JH (2006) Reorganization of actin filaments enhances chondrogenic differentiation of cells derived from murine embryonic stem cells. Biochem Biophys Res Comm 348: 421-427.

\section{Discussion with Reviewers}

Reviewer I: Cells were processed from limb buds using standard techniques, and then given 18 hours to recover. Do masses not form otherwise?

Authors: Cells were not plated out at a high enough density to allow masses to form within this timeframe.

Reviewer II: What happens to cells placed in the device with no ultrasound application? Do they adhere to the bottom surface or eventually aggregate with one another due to Brownian motion? How does this compare to cells plated in an 'over agarose' type assay where adhesion is blocked?

Authors: The long-term behaviour of cells on the surface of the USWT has not been studied, and so it is not possible to comment on this. The USWT was designed to eliminate cell-substratum interactions and to study cell behaviour immediately following contact, rather than for more longterm applications. It would have been interesting, of course, to follow the long-term behaviour of cells in the USWT, but this would have required significant technological development, e.g. the development of an USWT that can be remotely powered and controlled from inside an incubator, with real-time microscopic analysis.

Reviewer III: The evaluation of physical integrity is interesting and valuable. How quantitative is this measure, and has it previously be published? It is later noted that chondrocytes take a much longer time to form robust pellets - what is the mechanism for this? Has sedimentation strength been assayed using specific blockers of either actin or other cell adhesion molecules to show how this integrity is derived? In a later figure, some relationship is shown between actin localization and this phenomenon, but further study might be warranted.

Authors: The evaluation of physical integrity of cell aggregates in the USWT has been addressed in a number of studies (Coakley et al., 2004; Edwards et al., 2007). The reason why it takes longer for chondrocytes to form robust pellets is not known-aggregates formed may have reduced strength when used in other applications, for instance, immunofluorescence-this is a probable reason for why smaller numbers of interacting cells are shown where indirect immunofluorescence labelling of Sox 9 was carried out-cells were exposed to more experimental steps than those used for actin labelling.

A study carried out by a final-year B.Sc. student addressed the relationship between actin localization and aggregate strength, using HepG2 cells treated with Cytochalasin D (unpublished data). Aggregates treated with Cytochalasin D were less physically stable than untreated aggregates, and cell membrane spreading was inhibited following initial cell contact. These results demonstrate that when cells come into contact with one another, initial F-actin reorganization drives morphological changes and enhances cell-cell adhesion. This is a biological response, and is not due to cells being forced together in the ultrasound trap.

Reviewer III: How do USWT masses act over a longer time course? Are proteoglycans and collagens produced as is seen in a normal micromass culture system? Does this occur over the same time course, or faster when aggregates were assembled with the USWT?

Authors: Please also refer to comments for the previous question. Whilst this is in interesting question, the study was not designed to look at the long-term behaviour of USWT aggregates. This would require technical modifications, e.g. the development of an USWT that could be placed in a cell culture incubator, or the removal of aggregates from the USWT following formation and subsequent alginate encapsulation (e.g. Bazou, 2009). It would be tempting to speculate however that proteoglycan and collagen expression would occur more rapidly in USWT aggregates than in traditional micromass cultures (given a comparable starting point of plating out cells for a micromass culture or placing cells into the USWT) due to the fact that cells in the USWT are immediately brought together, which would facilitate the rapid development of cell-cell contacts in a manner comparable to prechondrogenic condensations in vivo.

\section{Additional Reference}

Bazou D (2009) Biochemical properties of encapsulated high-density 3-D HepG2 aggregates formed in an ultrasound trap for application in hepatotoxicity studies : Biochemical responses of encapsulated 3-D HepG2 aggregates. Cell Biol Toxicol [Epub ahead of print DOI: 10.1007/s10565-009-9123-0]. 